\title{
The multi-differentiation potential of peripheral blood mononuclear cells
}

\author{
Min Zhang and Bing Huang*
}

\begin{abstract}
Peripheral blood is a large accessible source of adult stem cells for both basic research and clinical applications. Peripheral blood mononuclear cells (PBMCs) have been reported to contain a multitude of distinct multipotent progenitor cell populations and possess the potential to differentiate into blood cells, endothelial cells, hepatocytes, cardiomyogenic cells, smooth muscle cells, osteoblasts, osteoclasts, epithelial cells, neural cells, or myofibroblasts under appropriate conditions. Furthermore, transplantation of these PBMC-derived cells can regenerate tissues and restore function after injury. This mini-review summarizes the multi-differentiation potential of PBMCs reported in the past years, discusses the possible mechanisms for this multi-differentiation potential, and describes recent techniques for efficient PBMC isolation and purification.
\end{abstract}

\section{Introduction}

Stem cells (SCs) were first isolated in the 1960s from the peripheral blood of dogs and used to cure hematopoietic failure following irradiation $[1,2]$. The preponderance of evidence now suggests that many or most adult tissues contain SCs with the capacity for tissue-specific differentiation. In the decades since SCs were isolated, several distinct progenitor cell populations have been reported in the peripheral blood mononuclear cell (PBMC) fraction, including hematopoietic stem cells (HSCs) [3], endothelial progenitor cells (EPCs) [4], mesenchymal stem cells (MSCs) [5], osteoclast precursor cells [6], hematopoietic osteoclast precursor cells [7], and a population of circulating fibrocytes [8], suggesting that PBMCs may possess the potential to differentiate into a multitude of mature functional cell types in specific microenvironments. Indeed, recent studies have

*Correspondence: huangbing2000@hotmail.com

State Key Laboratory of Ophthalmology, ZhongShan Ophthalmic Center,

Sun Yat-sen University, Guangzhou 510060, People's Republic of China confirmed that PBMCs can differentiate along alternative lineages in vitro and in vivo depending on culture conditions or the site of transplantation [9-11].

Blood is the most convenient source from which to obtain SCs from patients, and can be frozen and stored for later use. Moreover, numerous frozen samples are already stored in blood banks. Not only do PBMCs contain many distinct progenitor cell types, they can be expanded in culture and reprogrammed to induced pluripotent stem cells (iPSCs) [12-14] with broad clinical applications in regenerative medicine. The known multidifferentiation potential of PBMCs indicates that these cells may be a source of many functional cell types for regenerative therapy.

\section{Evidence for the multi-differentiation potential of PBMCs}

Differentiation of PBMCs into blood cells

Tavassoli and colleagues [15] reported that autologously transplanted bone marrow (BM) survived in various extramedullary sites in the rat, rabbit, and dog, and that this ectopic BM completely reconstituted the hematopoietic system. However, a significant impediment to allogeneic BM grafting is the procurement of a sufficient quantity of BM from a single living donor for rapid restoration of hematopoietic function [1]. Recent studies indicate that HSCs with marrow re-population potential are present in the PBMC population. Thus, reconstruction of the hematopoietic system may be possible by harvesting large numbers of HSCs using safe and minimally invasive PBMC fractionation and selection [2,16-18]. Furthermore, these SCs may allow for long-term restoration of hematopoiesis [19]. Indeed, many recent studies [20-22] have demonstrated that PBMCs can both self-propagate and differentiate into mature blood cells in vitro and in vivo.

Goldberg and colleagues [21] cultured human PBMCs (hPBMCs) in a conditioned medium obtained from adherent PBMCs incubated with 2-mercaptoethanol and obtained colony forming unit-granulocyte-macrophage progenitors. The ${ }^{3} \mathrm{H}$-thymidine-labeled proliferating cells appeared to be mononuclear cells as determined by autoradiographs. In addition, the granulocytic nature of these 
progenitor cells was also verified by the development of maturing progeny identified as promyelocytes, myelocytes, metamyelocytes, and both band- and polymorphonuclear-form granulocytes containing granules reactive to peroxidase stains and incorporating $\mathrm{Na}_{2}{ }^{35} \mathrm{SO}_{4}$. Human PBMCs can also produce other hematopoietic colonies, including colony forming unit-granulocyte-erythroidmonocyte-macrophage-megakaryocyte, colony forming unit-monocyte-macrophage, blast forming uniterythroid and colony forming unit-erythroid precursors during culture in a defined hematopoietic-conducive condition medium containing Iscove's modified Dulbecco's medium, fetal calf serum (FCS), horse serum, cortisol, and purified CR3/43 [23].

Dogs transplanted with GFP-transfected CD34PBMCs $\left(0.5 \times 10^{8}\right.$ cells $\left./ \mathrm{kg}\right)$ following 300 cGy total body irradiation exhibited peripheral white blood cell and platelet count recovery [24]. A BM biopsy after transplantation also showed GFP-expressing cells co-expressing osteocalcin, predominantly along the bone spicules ('bone lining cells'). There was also evidence that the engrafted CD34+ PBMC clones contributed long-term hematopoietic engraftment [25]. In another study, rhesus macaques received 500 cGy total body irradiation daily for two days, then were infused with autologous CD34+ PBMCs that had been expanded in vitro and infected with a retroviral vector gene (neo). Hematopoietic recovery was monitored by daily complete blood counts for up to one year post-transplantation. Animals infused with transduced CD34+ cells exhibited fastest recovery of T-cell numbers, especially naive $\mathrm{T}$ cells, compared to control irradiated animals. In a clinical study by Shadduck and colleagues [26] conducted from 1990 to 1997, more than 100 patients diagnosed with hemopoietic malignant tumors were treated by autologous CD34+ PBMC transplantation (with most patients receiving more than $4 \times 10^{6} \mathrm{CD} 34+$ cells $/ \mathrm{kg}$ ). Patients receiving transplants typically showed faster neutrophil recovery (counts greater than 500 by day 10 to 11 ) and platelet recovery, and required fewer red cell and platelet transfusions than expected for control patients, suggesting that autologous PBMCs are a promising alternative to BM for HSCs for transplantation [27-37].

\section{Differentiation of PBMCs into endothelial cells}

Endothelial progenitor cells present in BM, peripheral blood and umbilical cord blood possess the capacity to directionally differentiate into mature endothelial cells (ECs) for revascularization at sites of ischemia, thus recapitulating an important developmental induction pathway for postnatal angiogenesis [38]. Putative EPCs were first isolated from human peripheral blood by magnetic bead selection and it was found that these cells could differentiate into ECs in vitro and incorporate into sites of active angiogenesis in animal models of ischemia [4]. There are two different types of EPCs circulating in adult human peripheral blood, early and late colonies. The late colonies appeared to be a better source for angiogenic therapy [39-43].

When hPBMCs were cultured on fibronectin- or gelatin-coated dishes in endothelial medium (EGM-2 or M-199), adherent clusters of cells appeared that formed cord-like or duct-like structures, and individual cells became spindle-shaped, reminiscent of cultured ECs. Most of these cells (85\%) were positive for the EC markers CD31, CD34, Flk-1, and von Willebrand factor, expressed EC-typical genes like Flt-1, Flk-1, ecNOS and tie-2, and accumulated DiI-Ac-LDL $[39,41,42]$.

Different from the culture mentioned above, Joensuu and colleagues [44] established a novel co-culture system of human BM-derived MSCs and PBMCs growing in monolayer cultures on bovine collagen. Co-culture resulted in the formation of PECAM-1- and endoglinpositive vessel-like structures, expressing vascular endothelial growth factor receptor 1 (VEGFR1). By contrast, no PECAM-1-, endoglin- or VEGFR1-expressing cells were found in MSC cultures without PBMCs [44], indicating that PBMC-derived factors are necessary for EC differentiation. This co-culture system is much more convenient than that using EC medium because no additional growth factors or extracellular matrix proteins are needed for EC differentiation.

Yeh and colleagues [45] transplanted human CD34+ PBMCs (about two and a half million per animal) into the left ventricle of female SCID mice after myocardial infarction (MI). Using human leukocyte antigen (HLA) as a marker for the donor cells, double staining of the blood vessels with anti-HLA and anti-VE-cadherin suggested that human CD34+ cells differentiated into mature ECs within 2 months. Rat PBMC-derived MSCs have similar morphological and antigenic characteristics to BM-derived MSCs [46]. Following intravenous injection of PBMC-derived MSCs harboring LacZ into rats subjected to permanent middle cerebral artery occlusion, abundant LacZ-positive cells were found in and around the ischemic lesion. Furthermore, these rats exhibited hemodynamic changes indicative of cerebral reperfusion as revealed by perfusion-weighted MR imaging and functional recovery as assessed by the treadmill stress test.

Pretreatment with granulocyte colony-stimulating factor can mobilize EPCs from the BM to peripheral blood [47-49]. Mobilized rabbit PBMC-derived MSCs promote active angiogenesis at ischemia sites, reduce the area of ischemic damage and improve myocardial function following carotid artery balloon catheterization [50]. In an open clinical trial, Ishida and colleagues [51] implanted autologous PBMCs mobilized with granulocyte colony-stimulating factor in six patients with severe 
peripheral arterial disease and found significant improvements in limb ischemia as evidenced by improved anklebrachial pressure index and reduced ischemic ulcers. The mean maximum walking distance of these patients also increased from $203 \mathrm{~m}$ to $559 \mathrm{~m}$ and these improvements were sustained for 24 weeks. In addition, significant improvement was seen in the physiological functioning subscale of the Short Form-36 health survey.

\section{Differentiation of PBMCs into hepatocytes}

Human PBMCs have the potential to differentiate into hepatocyte-like cells in vitro in the presence of hepatocyte growth factor or fibroblast growth factor (FGF)-4 [52]. During induction culture, cells gradually rounded but did not assume the polygonal shape of mature hepatocytes, which might suggest additional signals (present in vivo) are required for full differentiation [52].

However, a subtype of CD34+ SCs derived from hPBMCs may provide a ready source of hepatocyte precursors. These CD34+ SCs can be divided into two populations, adherent and non-adherent to plastic culture plates, with distinct morphologies, phenotypes, and gene expression patterns [53]. Only the adherent CD34+ population had the capacity to differentiate into functional hepatocytes. A clinical study by Korbling and colleagues [54] further demonstrated this point; hPBMCs contain a population of CD34+ SCs that can differentiate into liver cells after transplantation. Six female patients with hematologic cancers or breast cancer received PBMCderived CD34+ SCs from a male donor, and biopsies were examined for the presence of donor-derived epithelial cells and hepatocytes using fluorescence in situ hybridization of interphase nuclei and immunohistochemical staining for cytokeratin, leukocyte common antigen CD45, and a hepatocyte-specific antigen. Hostdonor chimeric tissues were detected in the skin, liver, and gastrointestinal tract by restriction-fragment-length polymorphism analysis, and XY-positive epithelial cells or hepatocytes accounted for 0 to $7 \%$ of the cells in histological sections of the biopsy as indicated by a DNA probe specific for the centromeres of the $\mathrm{X}$ and $\mathrm{Y}$ chromosomes. The XY-positive hepatocytes were large, with round nuclei, and contained abundant granular cytoplasm, consistent with functional hepatocytes [54]. The origin of this CD34+ SC subpopulation and the mechanisms guiding differentiation into hepatocytes are unknown. One possibility is that PBMCs contain multiple lineage-restricted $\mathrm{SCs}$ that can differentiate independently into functional cells within the corresponding mature tissue [54].

\section{Differentiation of PBMCs into muscle cells}

A distinct population of smooth muscle progenitor cells may also be present in the hPBMC population [55]. Growth factors such as transforming growth factor and platelet-derived growth factor BB participate in smooth muscle cell (SMC) differentiation [56-58]. Integrins and other surface adhesion molecules are essential for vascular SMC adhesion, matrix assembly, proliferation, and for homing to specific target sites, especially $\beta 1$ integrin, the most abundant integrin expressed by proliferating SMCs in vivo [59-61]. Human PBMCs grown in platelet-derived growth factor BB-enriched medium differentiated into smooth muscle outgrowth cells that were positive for SMC-specific actin (SMA), myosin heavy chain, and calponin at both the mRNA and protein levels [55,62].

The PBMC population can also differentiate into cells with the characteristics of cardiomyocytes under appropriate conditions. Human PBMCs in 5-azacytidinecontaining medium manifest a spindle-like appearance and tend to form colonies of cells expressing myosin, sarcomeric actin, troponin $\mathrm{T}$ and desmin [63]. Unmobilized adult hPBMCs can also be induced to differentiate into cardiomyogenic progenitor cells under a defined cardiomyogenic-conducive condition of ES or long-term culture (LTC) medium containing $3.5 \mu \mathrm{g} / \mathrm{ml}$ purified CR3/4 [23]. In 'hanging drop' culture, colonies of these cells resembled beating embryoid bodies capable of synchronous rhythm. Moreover, these cells were able to differentiate into mature cardiomyocytes after implantation into the myocardium of non-irradiated, noninfarcted Rnu/Rnu nude rats [64].

Several in vivo studies have also suggested that PBMCs contribute to SMCs and cardiomyocytes after transplantation. Zhang and colleagues [65] found that hPBMCs could participate in the regeneration of the ischemic heart by differentiating into cardiomyocytes, vascular ECs, and SMCs after transplantation into mice and rabbit models of myocardial infarction. Their study also showed that mouse MHC-H2D was not expressed in the human HLA positive cells, suggesting no cell membrane fusion between transplanted cells and host cells. Badorff and colleagues [66] transplanted human PBMC-derived CD34+ cells into the infarcted myocardium of SCID mice. Using human HLA as a marker for the donor cells, double staining for HLA and SMA indicated that human CD34+ cells could differentiate into cells with mature cardiomyocyte morphology. Moreover, these cells integrated into the myocardium of the peri-infarct area and participated in the neovascularization after acute myocardial infarction. The frequency of PBMC-derived CD34+ cell differentiation was extremely low in uninjured hearts, however, indicating that differentiation or homing depends on signals released from injured heart tissue [45].

\section{Differentiation of PBMCs into bone}

Zvaifler and colleagues [5] first reported a precursor cell population within the normal human CD34- PBMC 
fraction, termed peripheral blood-derived MSCs, that adhered to plastic and glass and proliferated logarithmically in DMEM medium supplemented with FCS. These cells could assume fibroblast-like and stromal morphologies, and this differentiation was not affected by eliminating CD34+, CD3+, or CD14+ cells from the original PBMC population. After the osteogenic supplements dexamethasone, ascorbic acid, and $\beta$-glycerophosphate were added to the culture, fibroblast formation was inhibited, and cells assumed the cuboidal shape of osteoblasts (OBs). Elutriated cells displayed the alkaline phosphatase and osteocalcin expression characteristic of OBs. A study by Wan and colleagues [67] showed that rabbit allogeneic MSCs derived from PBMCs and transplanted into porous calcium phosphate resorbable substitutes enhanced bone regeneration in the rabbit ulna 20-mm critical-sized bone defect model, as evidenced by serial radiography, peripheral quantitative computed tomography and histological examination.

Numerous studies have reported that osteoclasts (OCs) can be generated from colony forming unit-granulocytemacrophage progenitors as well as from the PBMC population [68-77]. Costa-Rodrigues and colleagues [78] reported that the whole PBMC fraction and CD14+ PBMCs, but not CD14- PBMCs, survived in the absence of osteoclastogenic factors and exhibited spontaneous osteoclastogenesis as detected by cell type-specific protein and gene expression, TRAP activity, calcium phosphate resorption, and production of F-actin rings. Unlike CD14+ PBMCs, the total PBMC population was able to express macrophage colony-stimulating factor and RANKL (receptor activator of nuclear factor kappa$B$ ligand), as well as tumor necrosis factor-a, granulocytemacrophage colony-stimulating factor, IL-1, IL-6, and IL17 , which are necessary for osteoclastogenesis $[8,69]$. While CD14- PBMC cultures exhibited limited cell survival and only a few typical OC features, this population may serve to positively modulate osteoclastogenesis [8,78]. In addition, OBs under hypoxic stress can signal the conversion of PBMCs to OCs, and $\mathrm{OC}$ formation was correlated with hypoxia inducible factor$1 \alpha$-dependant upregulation of RANKL expression and VEGF release from OBs, which are critical for bone regeneration [79-85].

\section{Differentiation of PBMCs into epithelial cells}

The protein $14-3-3 \sigma$ has been described as a highly specific marker for epithelial cells that may aid greatly in the study of the differentiation of PBMCs into epithelial cells [86,87]. Medina and colleagues [88] found that a medium containing 49\% DMEM, 49\% keratinocyte serum-free medium, and 2\% FCS supported the differentiation of hPBMCs into epithelial-like cells and their long-term survival (more than 50 days). Human PBMCs started to express 14-3-36, keratin-5 and keratin- 8 in culture, while dermal fibroblasts expressed matrix metalloproteinase (MMP)-1 after treatment with PBMCconditioned medium [88].

It was also reported that CD34+ PBMCs accelerated neovascularization and epidermal healing in a model of chronic full-thickness skin wound in diabetic mice [89]. Circulating stem cells derived from CD34+ PBMCs could differentiate into mature epithelial cells of the skin, lung, and gastrointestinal tract following transplantation into sex-mismatched recipients [54]. Biopsy specimens from the skin and gastrointestinal tract of females after transplantation exhibited $\mathrm{X}$ and $\mathrm{Y}$ chromosome signals in cytokeratin-positive cells as revealed by fluorescence in situ hybridization. In epidermal tissue of the skin, donorderived cells were located in the deep layer of Malpighi (the stratum spinosum of the stratum germinativum), close to the dermal-epidermal junction and the stratum granulosum. Moreover, in the glandular epithelium of the gastric cardia, cells containing the $\mathrm{Y}$ chromosome were found in the foveola or tubular pits of the superficial glandular layer, which is composed of mucus-containing cells lining the foveola [54].

\section{Differentiation of PBMCs into neural cells}

Several papers have demonstrated neural differentiation from hPBMCs under different in vitro microenvironments. Horschitz and colleagues [90] developed two protocols for neural differentiation from hPBMCs. Method A used all-trans retinoic acid, epidermal growth factor (EGF), and basic FGF (bFGF), while method B used EGF, FGF8b, sonic hedgehog, and ascorbic acid. Both culture methods yielded neuronal cells, as evidenced by changes in morphology and the expression of the neuronal markers microtubule-associated protein type 2 , tau, and $\beta$-tubulin III. The second protocol resulted in predominantly dopaminergic neurons as indicated by the expression of the dopamine transporter. Abuljadayel [23] found neurons producing glutamate, GABA, tyrosine, dopamine, or serotonin as well as neurons accumulating taurine in $\mathrm{hPBMC}$ cultures in an ES medium, consisting of DMEM, FCS, L-glutamine, MEM non-essential amino acids, and $\beta$-2-mercaptoethanol. In addition, Liu and colleagues [91] showed that normal hPBMCs could be induced to differentiate into neural-like cells in a defined neural stem cell medium mainly containing DMEM/F12, B27, bFGF, EGF, FCS, Lglutamine, and MEM non-essential amino acids, or when exposed to conditioned medium from rat retinal tissue cultures. Moreover, PBMCs pre-induced in a defined neural stem cell medium migrated into the retina of nude mouse after vitreous cavity transplantation [91].

Several precursor cell populations isolated from PBMCs can also differentiate into either neurons or glia 
under appropriate conditions in vitro and in vivo [92-94]. Kim and colleagues [95] reported that MSCs isolated from PBMCs could be successfully induced to form neurospheres in the presence of EGF and bFGF and to differentiate into neural cells in vitro, suggesting a potential source for neural progenitors to treat central nervous system diseases. Kijima and colleagues [96] showed that human CD133+ PBMCs transplanted locally into a rat neural defect could induce vasculogenesis, providing an improved microenvironment for axonal regeneration; indeed, CD133+ cell implantation resulted in nerve reconstruction with abundant Schwann cells and myelinated axons. Moreover, the human GAPDH gene was detected in regenerated nerve tissue at eight weeks after transplantation. These studies strongly suggest that PBMCs have significant potential for establishing a nerve-regenerating microenvironment or a regeneration-conducive 'biological bridge'.

\section{Differentiation of PBMCs into myofibroblasts}

While studying acute cellular responses in a model of wound repair, Fahey and colleagues [97] observed large numbers of adherent, spindle-shaped cells that resembled fibroblasts and secreted a unique profile of cytokines, growth factors, and chemokines. The appearance of these cells was attributed to recruitment from surrounding subcutaneous tissue and suggests that a cell population arising from the PBMCs may participate in wound healing and connective tissue formation. Subsequent studies have provided direct evidence that myofibroblasts may be derived from PBMCs $[98,99]$.

A novel population of PBMCs with fibroblast properties, termed 'fibrocytes', was characterized by its distinctive CD45+/CD34+/CD14- phenotype [8]. Fibrocytes from human male PBMCs rapidly and specifically entered sites of tissue injury in female mice after transplantation [8]. Mori and colleagues [100] also reported a CD45+/CD34+/CD14- fibrocyte population in the PBMC fraction and demonstrated invasion of male PBMC-derived fibrocytes into wounds after transplantation in female mice previously exposed to total body irradiation. These results strongly suggest that circulating fibrocytes contribute to the myofibroblast population in the wound as well as to the marked increase in the number of cells expressing $\alpha$-SMA in the granulation tissue [94]. Then $\mathrm{Hu}$ and colleagues $[7,101]$ subsequently reported a CD14- cell population from PBMCs with both mesenchymal and hematopoietic features, designated peripheral blood multipotential mesenchymal progenitors. After transplant into a skin wound model, these progenitors differentiated into fibroblasts and participated in both extracellular matrix secretion and epidermal regeneration. Different from the work described above, Abe and colleagues [102] reported a CD14+
PBMC population with the capacity to differentiate into a-SMA1-positive, transforming growth factor-b1-responsive fibrocytes with characteristics similar to woundhealing myofibroblasts, including transient presence within the wound and production of numerous inflammatory cytokines and growth factors.

\section{Transformation of PBMCs into iPSCs}

Takahashi and colleagues [103] were the first to successfully reprogram adult human fibroblasts into a pluripotent state. Subsequent studies were able to obtain iPSCs from primary fetal tissues (lung, skin), neonatal fibroblasts, adult fibroblasts, and MSCs by constitutively expressing four transcription factors, Oct3/4, Sox2, Klf4, and c-Myc [104-106].

Loh and colleagues [13] first reported the derivation of iPSCs from multiple human PBMCs harvested by routine venipuncture. The resultant human iPSCs were similar to human embryonic stem cells in morphology, proliferation, surface antigens, gene expression patterns, epigenetic status of pluripotent cell-specific genes, and telomerase activity. Furthermore, like embryonic stem cells, iPSCs can differentiate into cell types from all three germ layers in vitro and in teratomas. The ectopic expression of Oct4, Sox2, Klf4, and c-Myc in GMP (clinical)-grade PBMCs and hematopoietic progenitor cells resulted in their rapid transition to iPSCs [107]. Human PBMCs can be isolated with minimal risk to the donor and obtained in sufficient numbers to enable reprogramming under GMP conditions, making them an ideal somatic cell source for clinical-grade patientspecific iPSCs.

\section{Possible mechanisms for the multi-differentiation potential of PBMCs}

To date, many papers on the multi-differentiation potential of PBMCs have been published, but the biological mechanisms of this potential are poorly understood. Several hypotheses have been proposed.

One possible biological mechanism is that multiple lineage-restricted progenitor cells circulate in the blood and can differentiate independently into their corresponding mature tissues [54]. Indeed, many phenotypically distinct progenitor cells have been described in the PBMC population in both laboratory animals and humans [108]. The existence of HSCs was suggested as early as the mid-20th century [109], then subsequent studies found that relatively few HSCs circulate in the peripheral blood of healthy donors and participate in the restoration of hematopoietic function [3,108]. Endothelial progenitors were isolated from hPBMCs by magnetic bead selection in 1997 and can differentiate into ECs [4]. Mesenchymal stem cells with the capacity for selfrenewal and the potential to differentiate into bone, 
cartilage, fat, tendon, muscle, nerve, and other specified tissues [109-111] were also found in peripheral blood and maintained in culture [50,112-114]. OC precursor cells, hematopoietic OC precursor cells, and a population of blood-derived, plastic-adherent HSC clones with MSC characteristics were also isolated from PBMCs $[7,18,102]$. In addition, circulating fibrocytes, a distinct mesenchymal cell type, were demonstrated in cultures derived from the PBMC fraction of whole blood $[8,102]$. Circulating fibrocytes could possess either monocyte-like or fibroblast-like characteristics, and were shown to have multilineage differentiation capacity (including the potential to differentiate into bone, fat, muscle and other tissue types) under appropriate conditions in vitro $[9,11,100]$. Injury and neoplasia are believed to be responsible for homing these progenitor cells to injury areas where they participate in tissue repair [100].

Cell retrodifferentiation, the reversal of the differentiation program and genomic reprogramming of differentiated adult cells to generate progenitor or stem cells, is also proposed to be one possible biological mechanism for this multi-differentiation potential of PBMCs [23,115118]. The local microenvironment, including solid support structures and signaling matrix components, as well as tissue-specific cytokines, and growth factors are responsible for the cell retrodifferentiation [9].

Cell fusion may also underlie some instances of multidifferentiation. OCs formed by the fusion of mononuclear precursors of the monocyte/macrophage lineage present in the peripheral circulation have been demonstrated in vitro, although there is no conclusive evidence to suggest that OCs can also be formed from the fusion of PBMCs [119-120]. It is possible, however, that PBMCs undergo nuclear division but not cytokinesis [73]. Cell fusion may also underlie the tissue-specific differentiation after transplantation in vivo [121]. However, fusion alone may not underlie all the multi-differentiation potential of PBMCs by using the multi- and high-specific techniques $[45,54,96]$.

It is also possible that PBMC-derived SCs committed to differentiation along a particular pathway can switch to another lineage under the influence of signals within the local microenvironment [54]. To maintain viability and retain the ability to proliferate, stem cells need cellto-cell contact and a microenvironment that provides an adequate supply of the necessary growth factors, which act in an autocrine or paracrine fashion [24]. Direct cellcell interactions may play a more important role than paracrine effects in inhibiting cell differentiation [24].

It is clear now that both robust, sustained, multilineage engraftment and functional activity representative of multiple phenotypic characteristics of the converted cells are required to show full differentiation [9]. But most of the studies on the differentiation potential of PBMCs are still based on visible morphological changes of the cultured cells and engrafted cells, and on immunohistochemistry, which is insufficient to conclude the occurrence of differentiation $[39,42,44,52,90]$. Besides, in most of the published studies, the data indicate that differentiation occurs very infrequently [12-14,54]. To enrich the foundation of PBMCs in research and regenerative therapy, scientists need to make more effort to understand the biological mechanism of this multidifferentiation potential.

\section{Methods for the isolation and purification of PBMCs}

Unleashing the full potential of PBMCs for regenerative medicine requires reliable methods for isolation and purification, techniques that have been gradually refined and improved over the past several decades.

At present, the most common methods for isolating PBMCs from peripheral blood are apheresis and density gradient centrifugation, with apheresis used more often to isolate PBMCs from patients for clinical use [122]. Large numbers of PBMCs can be isolated safely and conveniently from peripheral blood using an automated apheresis separator. Multiple studies have confirmed the presence of large quantities of pluripotential stem cells in cytapheresis products collected from healthy donors [20,122-126]. These cells can be successfully stored for later use in liquid nitrogen using DMSO as a cryoprotectant. Density gradient centrifugation $[4,6-8,97,98]$, especially over ficoll-paque, is more widely used to isolate PBMCs from whole heparinized peripheral blood (including peripheral blood already stored in blood banks) for further use. Occasionally, the PBMC fraction isolated by density gradient centrifugation is then mixed with a red blood cell lysis solution (such as $0.83 \% \mathrm{NH}_{4} \mathrm{Cl}$ solution) to destroy the mixed red blood cells for further PBMC purification [92,45].

After isolating the PBMCs from peripheral blood, specific progenitor cells (for example, HSCs, MSCs and EPCs) can be purified. Magnetic bead activated cell sorting (MACS) is widely used for purifying a specific progenitor cell population from PBMCs according to cellular phenotype; for example, CD34 microbeads are used to purify CD34+ HSCs, CD133 microbeads are used to purify CD133+ cells and EPCs, and CD14 microbeads are used to isolate CD14+ monocytes $[5,19,86,38,127]$. However, both the quantity and activity of these cells may be decreased after purification by MACS, so gentler substrate adhesion and negative selection protocols are becoming more common. In earlier studies, T-cell depletion was used to remove nonadherent cells by a nonimmune rosette sedimentation technique [15]. Alternatively, Kim and colleagues [95] selected the MSC population from PBMCs and eliminated the nonadherent 
cells by simply replacing the medium 48 hours after cell seeding. Human PBMC-derived stem/precursor cells were also purified using a negative selection human progenitor cell enrichment kit with CD41 depletion $[87,128]$. Yang and colleagues [62] established a method for directionally generating late EPCs and HSCs from hPBMCs by adhesion onto gelatin- and fibronectincoated culture plates.

\section{Conclusion}

PBMCs have been studied for more than 50 years. hPBMCs contain a multitude of distinct multipotent progenitor cell populations and posses the potential to differentiate into almost all cells of the three embryonic layers, including blood cells, ECs, hepatocytes, cardiomyogenic cells, muscle cells, OBs, OCs, epithelial cells, neural cells and myofibroblasts. Moreover, PBMCs can be reprogrammed to iPSCs, further expanding the phenotypic conversion potential of these cells. Techniques for isolation and purification of specific PBMC populations are gradually improving, and it is now possible to obtain pure populations from the PBMC fraction.

PBMCs may be superior to other cell sources for cellbased therapy. In contrast to BM or other sources of multipotent cells, the isolation of peripheral blood is minimally invasive, and does not require general anesthesia. In addition, autologous PBMC transplantation does not require long-term immunosuppressive therapy and can be applied with no ethical limitations $[30,104,129,130]$. These advantages will accelerate the transition from cell therapies for animal models to clinical applications.

Human peripheral blood HSC transplantation is now a well established curative treatment for patients with various hematologic malignancies [131], and techniques that exploit the multi-differentiation potential of PBMCs could lead to the isolation of cells for the treatment of presently incurable non-hematologic diseases as well [132-135]. However, many preclinical studies are still needed to better characterize the PBMC population and understand the biological mechanism of their multidifferentiation, and to further define their differentiation capacity, transplantability and biosafety.

\section{Abbreviations}

bFGF, basic fibroblast growth factor; BM, bone marrow; DMEM, Dulbecco's modified Eagle's medium; EC, endothelial cell; EGF, epidermal growth factor; EPC, endothelial progenitor cell; FCS, fetal calf serum; FGF, fibroblast growth factor; GFP, green fluorescent protein; HLA, human leukocyte antigen; hPBMC, human peripheral blood mononuclear cell; HSC, hematopoietic stem cell; IL, interleukin; iPSC, induced pluripotent stem cell; MACS, magnetic bead activated cell sorting; MSC, mesenchymal stem cell; OB, osteoblast; OC, osteoclast; PBMC, peripheral blood mononuclear cell; RANKL, receptor activator of nuclear factor kappa-B ligand; SC, stem cell; SMA, SMC-specific actin; SMC, smooth muscle cell; VEGF, vascular endothelial growth factor.

\section{Competing interests}

The authors declare that they have no competing interests.

\section{Acknowledgments}

We are grateful for financial support from the Science and Technology Projects of Guangdong Province, China (2009B060600002, 2010B060500006).

Published: 30 November 2012

\section{References}

1. Storb R, Epstein RB, Ragde H, Bryant J, Thomas ED: Marrow engraftment by allogeneic leukocytes in lethally irradiated dogs. Blood 1967, 30:805-811.

2. Cavins JA, Scheer SC, Thomas ED, Ferrebee JW: The recovery of lethally irradiated dogs given infusions of autologous leukocytes preserved at -80 C. Blood 1964, 23:38-42.

3. Damon LE, Damon LE: Mobilization of hematopoietic stem cells into the peripheral blood. Expert Rev Hematol 2009, 2:717-733.

4. Asahara T, Murohara T, Sullivan A, Silver M, van der Zee R, Li T, Witzenbichler B, Schatteman G, Isner JM: Isolation of putative progenitor endothelial cells for angiogenesis. Science 1997, 275:964-967.

5. Zvaifler NJ, Marinova-Mutafchieva L, Adams G, Edwards CJ, Moss J, Burger JA, Maini RN: Mesenchymal precursor cells in the blood of normal individuals. Arthritis Res 2000, 2:477-488

6. Costa-Rodrigues J, Teixeira CA, Sampaio P, Fernandes MH: Characterisation of the osteoclastogenic potential of human osteoblastic and fibroblastic conditioned media. J Cell Biochem 2010, 109:205-216.

7. Hu G, Xu JJ, Deng ZH, Feng J, Jin Y: Supernatant of bone marrow mesenchymal stromal cells induces peripheral blood mononuclear cells possessing mesenchymal features. Int J Biol Sci 2011, 7:364-375.

8. Bucala R, Spiegel LA, Chesney J, Hogan M, Cerami A: Circulating fibrocytes define a new leukocyte subpopulation that mediates tissue repair. Mol Med 1994, 1:71-81.

9. Anderson DJ, Gage FH, Weissman IL: Can stem cells cross lineage boundaries? Nat Med 2001, 7:393-395.

10. Ilic D, Polak JM: Stem cells in regenerative medicine: introduction. Br Med Bull 2011, 98:117-126

11. Singh MS, MacLaren RE: Stem cells as a therapeutic tool for the blind: biology and future prospects. Proc Bio/ Sci 2011, 278:3009-3016.

12. Seki T, Yuasa S, Oda M, Egashira T, Yae K, Kusumoto D, Nakata H, Tohyama S, Hashimoto H, Kodaira M, Okada Y, Seimiya H, Fusaki N, Hasegawa M, Fukuda $\mathrm{K}$ : Generation of induced pluripotent stem cells from human terminally differentiated circulating T cells. Cell Stem Cell 2010, 7:11-14.

13. Loh YH, Hartung O, Li H, Guo C, Sahalie JM, Manos PD, Urbach A, Heffner GC, Grskovic M, Vigneault F, Lensch MW, Park IH, Agarwal S, Church GM, Collins Jر, Irion S, Daley GQ: Reprogramming of T cells from human peripheral blood. Cell Stem Cell 2010, 7:15-19.

14. Staerk J, Dawlaty MM, Gao Q, Maetzel D, Hanna J, Sommer CA, Mostoslavsky $G$, Jaenisch R: Reprogramming of human peripheral blood cells to induced pluripotent stem cells. Cell Stem Cell 2010, 7:20-24.

15. Tavassoli M, Crosby WH: Transplantation of marrow to extramedullary sites. Science 1968, 161:54-56.

16. Goodman JW, Hodgson GS: Evidence for stem cells in the peripheral blood of mice. Blood 1962, 19:702-714.

17. Malinin TI, Perry VP, Kerby CC, Dolan MF: Peripheral leukocyte infusion into lethally irradiated guinea pigs. Blood 1965, 25:692-703.

18. Till JE, McCulloch EA: A direct measurement of the radiation sensitivity of normal mouse bone marrow cells. Radiat Res 1961, 14:213-222.

19. Van Beusechem VW, Valerio D: Gene transfer into hematopoietic stem cells of nonhuman primates. Hum Gene Ther 1996, 7:1649-1668.

20. Metcalf D: The colony stimulating factor (CSF). Aust J Exp Biol Med Sci 1972, 50:547-557.

21. Goldberg J, McGuire LA, Williams WJ: Myeloid differentiation of human blood mononuclear cells in liquid culture. Blood 1981, 57:497-504.

22. Yoshino H, Watanabe N, Takahashi K, Ogura K, Akagi T, Kubo K, Kashiwakura I: The potential of patients' peripheral blood mononuclear cells to differentiate into dendritic cells after hematopoietic stem cell transplantation. Life Sci 2011, 89:946-955.

23. Abuljadayel IS: Induction of stem cell-like plasticity in mononuclear cells derived from unmobilised adult human peripheral blood. Curr Med Res Opin 2003, 19:355-375.

24. Huss R, Lange C, Weissinger EM, Kolb HJ, Thalmeier K: Evidence of peripheral 
blood-derived, plastic-adherent CD34(-/low) hematopoietic stem cell clones with mesenchymal stem cell characteristics. Stem Cells 2000 18:252-260.

25. Lore K, Seggewiss R, Guenaga FJ, Pittaluga S, Donahue RE, Krouse A, Metzger ME, Koup RA, Reilly C, Douek DC, Dunbar CE: In vitro culture during retroviral transduction improves thymic repopulation and output after total body irradiation and autologous peripheral blood progenitor cell transplantation in rhesus macaques. Stem Cells 2006, 24:1539-1548.

26. Shadduck RK, Zeigler ZR, Andrews DR, Gilmore GL, Lister J: Mobilization and transplantation of peripheral blood stem cells. Stem Cells 1998, 16 Suppl 1:145-158.

27. Dreger P, Suttorp M, Haferlach T, Loffler H, Schmitz N, Schroyens W: Allogeneic granulocyte colony-stimulating factor-mobilized peripheral blood progenitor cells for treatment of engraftment failure after bone marrow transplantation. Blood 1993, 81:1404-1407.

28. Matsunaga T, Sakamaki S, Kohgo Y, Ohi S, Hirayama Y, Niitsu Y: Recombinant human granulocyte colony-stimulating factor can mobilize sufficient amounts of peripheral blood stem cells in healthy volunteers for allogeneic transplantation. Bone Marrow Transplant 1993, 11:103-108.

29. Korbling M, Przepiorka D, Huh YO, Engel H, van Besien K, Giralt S, Andersson $B$, Kleine HD, Seong D, Deisseroth AB, Deisseroth MA, Charnplin R: Allogeneic blood stem cell transplantation for refractory leukemia and lymphoma: potential advantage of blood over marrow allografts. Blood 1995 85:1659-1665.

30. Bensinger WI, Weaver CH, Appelbaum FR, Rowley S, Demirer T, Sanders J, Storb R, Buckner CD: Transplantation of allogeneic peripheral blood stem cells mobilized by recombinant human granulocyte colony-stimulating factor. Blood 1995, 85:1655-1658.

31. Bensinger WI, Clift R, Martin P, Appelbaum FR, Demirer T, Gooley T, Lilleby K, Rowley S, Sanders J, Storb R, Buckner CD: Allogeneic peripheral blood stem cell transplantation in patients with advanced hematologic malignancies: a retrospective comparison with marrow transplantation. Blood 1996 88:2794-2800

32. Schmitz N, Dreger P, Suttorp M, Rohwedder EB, Haferlach T, Loffler H, Hunter A, Russell NH: Primary transplantation of allogeneic peripheral blood progenitor cells mobilized by filgrastim (granulocyte colony-stimulating factor). Blood 1995, 85:1666-1672

33. Briones J, Urbano-Ispizua A, Lawler M, Rozman C, Gardiner N, Marin P, Salgado C, Feliz P, McCann S, Montserrat E: High frequency of donor chimerism after allogeneic transplantation of CD34+-selected peripheral blood cells. Exp Hematol 1998, 26:415-420.

34. Schmitz N, Bacigalupo A, Labopin M, Majolino I, Laporte JP, Brinch L, Cook G, Deliliers GL, Lange A, Rozman C, Garcia-Conde J, Finke J, Domingo-Albos A, Gratwohl A: Transplantation of peripheral blood progenitor cells from HLA-identical sibling donors. European Group for Blood and Marrow Transplantation (EBMT). Br J Haematol 1996, 95:715-723.

35. Bacigalupo A, Zikos P, Van Lint MT, Valbonesi M, Lamparelli T, Gualandi F, Occhini D, Mordini N, Bregante S, Berisso G, Vitale V, Sessarego M, Marmont AM: Allogeneic bone marrow or peripheral blood cell transplants in adults with hematologic malignancies: a single-center experience. Exp Hematol 1998, 26:409-414.

36. Schmitz N, Bacigalupo A, Hasenclever D, Nagler A, Gluckman E, Clark P, Bourquelot P, Greinix H, Frickhofen N, Ringden O, Zander A, Apperley JF, Gorin C, Borkett K, Schwab G, Goebel M, Russell NH, Gratwohl A: Allogeneic bone marrow transplantation vs filgrastim-mobilised peripheral blood progenitor cell transplantation in patients with early leukaemia: first results of a randomised multicentre trial of the European Group for Blood and Marrow Transplantation. Bone Marrow Transplant 1998, 21:995-1003.

37. Yang Z, Tao J, Tu C, Xu M, Wang Y, Wang J, Pan S: Differentiation of endothelial progenitor cells from healthy human peripheral blood mononuclear cells population in vitro. J Sun Yat-sen University (Med Sci) 2005, 26:14-15.

38. Li H, Gao JH, Yan L, Lu F, Zhu M: Biological characteristics of adult peripheral blood mononuclear cells differentiating into early and late endothelia progenitor cells in vitro. J Clin Rehabilitative Tissue Eng Res 2007, 11:4682-4685

39. Zhang SJ, Zhang H, Wei YJ, Su WJ, Liao ZK, Hou M, Zhou JY, Hu SS: Adult endothelial progenitor cells from human peripheral blood maintain monocyte/macrophage function throughout in vitro culture. Cell Res 2006 , 16:577-584

40. Zhang F, Han Z, Yang H, Qiu C, Zhang X, Chen Q, Li L, Huang Z: Different methods used for acquiring endothelial progenitor cells from human peripheral blood mononuclear cells population. Chin J Cardiovasc Rev 2007 5:914-917.

41. Yan Y, Sun B, Dai Q: Peripheral blood mononuclear cells differentiated into endothelial progenitor cells in vitro. Chin J Cardiovascu Rev 2005, 3:218-221.

42. Kawamoto A, Tkebuchava T, Yamaguchi J, Nishimura H, Yoon YS, Milliken C, Uchida S, Masuo O, Iwaguro H, Ma H, Hanley A, Silver M, Kearney M, Losordo DW, Isner JM, Asahara T: Intramyocardial transplantation of autologous endothelial progenitor cells for therapeutic neovascularization of myocardial ischemia. Circulation 2003, 107:461-468.

43. Rafii S, Lyden D: Therapeutic stem and progenitor cell transplantation for organ vascularization and regeneration. Nat Med 2003, 9:702-712.

44. Joensuu K, Paatero I, Alm JJ, Elenius K, Aro HT, Heino TJ, Hentunen TA: Interaction between marrow-derived human mesenchymal stem cells and peripheral blood mononuclear cells in endothelial cell differentiation. Scand J Surg 2011, 100:216-222.

45. Yeh ET, Zhang S, Wu HD, Korbling M, Willerson JT, Estrov Z: Transdifferentiation of human peripheral blood CD34+-enriched cell population into cardiomyocytes, endothelial cells, and smooth muscle cells in vivo. Circulation 2003, 108:2070-2073.

46. Ukai R, Honmou O, Harada K, Houkin K, Hamada H, Kocsis JD: Mesenchymal stem cells derived from peripheral blood protects against ischemia. J Neurotrauma 2007, 24:508-520.

47. Kocher AA, Schuster MD, Szabolcs MJ, Takuma S, Burkhoff D, Wang J, Homma S, Edwards NM, Itescu S: Neovascularization of ischemic myocardium by human bone-marrow-derived angioblasts prevents cardiomyocyte apoptosis, reduces remodeling and improves cardiac function. Nat Med 2001, 7:430-436

48. Takahashi T, Kalka C, Masuda H, Chen D, Silver M, Kearney M, Magner M, Isner JM, Asahara T: Ischemia- and cytokine-induced mobilization of bone marrow-derived endothelial progenitor cells for neovascularization. Nat Med 1999, 5:434-438.

49. Shi B, Zhao RZ, Xu GX, Wang DM, Shen CY: rhG.CSF promotes re-endothelialization and attenuates intima hyperplasia in carotid artery of rabbits post balloon catheter injury. Clin J Cardiol 2009, 37:441-444.

50. Liu ZJ, Shi B, Zhao RZ, Shen CY, Wang DM, Wang ZL: Effect of peripheral blood mesenchymal stem cells transplantation on neovascularization and cardiac function of myocardial infarction rabbits. Zhongguo Zuzhi Gongcheng Yanjiu yu Linchuang Kangfu 2011, 15:5039-5043.

51. Ishida A, Ohya Y, Sakuda H, Ohshiro K, Higashiuesato Y, Nakaema M, Matsubara S, Yakabi S, Kakihana A, Ueda M, Miyagi C, Yamane N, Koja K, Komori K, Takishita S: Autologous peripheral blood mononuclear cell implantation for patients with peripheral arterial disease improves limb ischemia. Circ J 2005, 69:1260-1265.

52. Shang $H$, Zhao G, Yang L: Differentiation of human peripheral blood mononuclear cells into hepatocyte-like cells in vitro. J Clin Rehabilitative Tissue Eng Res 2009, 13:1859-1863.

53. Gordon MY, Levicar N, Pai M, Bachellier P, Dimarakis I, Al-Allaf F, M'Hamdi H, Thalji T, Welsh JP, Marley SB, Davies J, Dazzi F, Marelli-Berg F, Tait P, Playford R, Jiao L, Jensen S, Nicholls JP, Ayav A, Nohandani M, Farzaneh F, Gaken J, Dodge R, Alison M, Apperley JF, Lechler R, Habib NA: Characterization and clinical application of human CD34+ stem/progenitor cell populations mobilized into the blood by granulocyte colony-stimulating factor. Stem Cells 2006, 24:1822-1830

54. Korbling M, Katz RL, Khanna A, Ruifrok AC, Rondon G, Albitar M, Champlin RE, Estrov Z: Hepatocytes and epithelial cells of donor origin in recipients of peripheral-blood stem cells. N Engl J Med 2002, 346:738-746.

55. Simper D, Stalboerger PG, Panetta CJ, Wang S, Caplice NM: Smooth muscle progenitor cells in human blood. Circulation 2002, 106:1199-1204.

56. Nakajima Y, Mironov V, Yamagishi T, Nakamura H, Markwald RR: Expression of smooth muscle alpha-actin in mesenchymal cells during formation of avian endocardial cushion tissue: a role for transforming growth factor beta3. Dev Dyn 1997, 209:296-309.

57. Hirschi KK, Rohovsky SA, D'Amore PA: PDGF, TGF-beta, and heterotypic cell-cell interactions mediate endothelial cell-induced recruitment of 10T1/2 cells and their differentiation to a smooth muscle fate. J Cell Biol 1998, 141:805-814

58. Hellstrom M, Kalen M, Lindahl P, Abramsson A, Betsholtz C: Role of PDGF-B and PDGFR-beta in recruitment of vascular smooth muscle cells and pericytes during embryonic blood vessel formation in the mouse. Development 1999, 126:3047-3055. 
59. Pickering JG, Chow LH, Li S, Rogers KA, Rocnik EF, Zhong R, Chan BM: alpha5beta1 integrin expression and luminal edge fibronectin matrix assembly by smooth muscle cells after arterial injury. Am J Pathol 2000, 156:453-465.

60. Yamamoto K, Yamamoto M: Cell adhesion receptors for native and denatured type I collagens and fibronectin in rabbit arterial smooth muscle cells in culture. Exp Cell Res 1994, 214:258-263.

61. Mercurius KO, Morla AO: Inhibition of vascular smooth muscle cell growth by inhibition of fibronectin matrix assembly. Circ Res 1998, 82:548-556.

62. Yang W, Yan Y, Hong J, Sun B: In vitro differentiation of peripheral blood mononuclear cells into smooth muscle progenitor cells. J Shanghai Jiaotong University (Med Sci) 2007, 27:307-310

63. Li W, Yan Y, Dai Q, Zhang Z, Zhu Y, Sun B: In vitro study of cardiomyocyte-like differentiation of human peripheral blood-derived mononuclear cells. Chin J Geriatr Heart Brain Vessel Dis 2007, 9:125-127.

64. Brooks CG, Webb PJ, Robins RA: Studies on the immunology of rnu/rnu nude rats with congenital aplasia of the thymus. Eur J Immunol 1980, 10:58-65.

65. Zhang Z, Yan Y, Zhu Y, Zhu G, Dai Q, Sun B: In vivo study on the potential differentiation capabilities of human peripheral blood-derived mononuclear cells transplanted into the nude mice with myocardial infarction. J Biomed Eng 2008, 25:424-428.

66. Badorff C, Brandes RP, Popp R, Rupp S, Urbich C, Aicher A, Fleming I, Busse R, Zeiher AM, Dimmeler S: Transdifferentiation of blood-derived human adult endothelial progenitor cells into functionally active cardiomyocytes. Circulation 2003, 107:1024-1032.

67. Wan C, He Q, Li G: Allogenic peripheral blood derived mesenchymal stem cells (MSCs) enhance bone regeneration in rabbit ulna critical-sized bone defect model. J Orthop Res 2006, 24:610-618.

68. Ciraci E, Barisani D, Parafioriti A, Formisano G, Arancia G, Bottazzo G, Berardi AC: CD34 human hematopoietic progenitor cell line, MUTZ-3, differentiates into functional osteoclasts. Exp Hematol 2007, 35:967-977.

69. Massey HM, Flanagan AM: Human osteoclasts derive from CD14-positive monocytes. Br J Haematol 1999, 106:167-170.

70. Komano Y, Nanki T, Hayashida K, Taniguchi K, Miyasaka N: Identification of a human peripheral blood monocyte subset that differentiates into osteoclasts. Arthritis Res Ther 2006, 8:R152.

71. Nicholson GC, Malakellis M, Collier FM, Cameron PU, Holloway WR, Gough TJ, Gregorio-King C, Kirkland MA, Myers DE: Induction of osteoclasts from CD14-positive human peripheral blood mononuclear cells by receptor activator of nuclear factor kappaB ligand (RANKL). Clin Sci (Lond) 2000, 99:133-140.

72. Komi J, Lassila O: Nonsteroidal anti-estrogens inhibit the functional differentiation of human monocyte-derived dendritic cells. Blood 2000, 95:2875-2882

73. Hodge JM, Kirkland MA, Aitken CJ, Waugh CM, Myers DE, Lopez CM, Adams BE, Nicholson GC: Osteoclastic potential of human CFU-GM: biphasic effect of GM-CSF. J Bone Miner Res 2004, 19:190-199.

74. Hemingway F, Cheng X, Knowles HJ, Estrada FM, Gordon S, Athanasou NA In vitro generation of mature human osteoclasts. Calcif Tissue Int 2011, 89:389-395.

75. Huang $H$, Jiang $H$, Zhang $H$, Hou J: Generating osteoclasts from human peripheral blood mononuclear cells. Int J Pathol Clin Med 2008, 28:10-13.

76. Chao A, Yang F, Wang L, Fang J, Li Y: The meaning of TRAP positive cells ratio while human peripheral blood cells inducing to osteoclast-like cells in vitro. Chin J Osteoporos 2007, 13:246-249.

77. Zeng RM, Jin DD, Zhang ZM: Induced differentiation of human peripheral blood CD68+ mononuclear cells into osteoclasts in vitro. J First Mil Med Univ 2004, 24:585-589.

78. Costa-Rodrigues J, Fernandes A, Fernandes MH: Spontaneous and induced osteoclastogenic behaviour of human peripheral blood mononuclear cells and their CD14(+) and CD14(-) cell fractions. Cell Prolif 2011, 44:410-419

79. Akeno N, Czyzyk-Krzeska MF, Gross TS, Clemens TL: Hypoxia induces vascular endothelial growth factor gene transcription in human osteoblast-like cells through the hypoxia-inducible factor-2alpha. Endocrinology 2001, 142:959-962.

80. Liu Y, Cox SR, Morita T, Kourembanas S: Hypoxia regulates vascular endothelial growth factor gene expression in endothelial cells. Identification of a 5' enhancer. Circ Res 1995, 77:638-643.

81. Schumacker PT: Hypoxia-inducible factor-1 (HIF-1). Crit Care Med 2005,
33(12 Suppl):S423-S425.

82. Akeno N, Robins J, Zhang M, Czyzyk-Krzeska MF, Clemens TL: Induction of vascular endothelial growth factor by IGF-I in osteoblast-like cells is mediated by the PI3K signaling pathway through the hypoxia-inducible factor-2alpha. Endocrinology 2002, 143:420-425.

83. Kim HH, Lee SE, Chung WJ, Choi Y, Kwack K, Kim SW, Kim MS, Park H, Lee ZH: Stabilization of hypoxia-inducible factor-1alpha is involved in the hypoxic stimuli-induced expression of vascular endothelial growth factor in osteoblastic cells. Cytokine 2002, 17:14-27.

84. Dandajena TC, Ihnat MA, Disch B, Thorpe J, Currier GF: Hypoxia triggers a HIF-mediated differentiation of peripheral blood mononuclear cells into osteoclasts. Orthod Craniofac Res 2012, 15:1-9.

85. Motokawa M, Tsuka N, Kaku M, Kawata T, Fujita T, Ohtani J, Matsuda Y, Terao A, Tanne K: Effects of vascular endothelial growth factor-C and -D on osteoclast differentiation and function in human peripheral blood mononuclear cells. Arch Oral Bio/ 2012 [Epub ahead of print].

86. Dellambra E, Golisano O, Bondanza S, Siviero E, Lacal P, Molinari M, D'Atri S, De Luca M: Downregulation of 14-3-3sigma prevents clonal evolution and leads to immortalization of primary human keratinocytes. J Cell Biol 2000, 149:1117-1130.

87. Pellegrini G, Dellambra E, Golisano O, Martinelli E, Fantozzi I, Bondanza S, Ponzin D, McKeon F, De Luca M: p63 identifies keratinocyte stem cells. Proc Natl Acad Sci U S A 2001, 98:3156-3161.

88. Medina A, Kilani RT, Carr N, Brown E, Ghahary A: Transdifferentiation of peripheral blood mononuclear cells into epithelial-like cells. Am J Pathol 2007, 171:1140-1152.

89. Sivan-Loukianova E, Awad OA, Stepanovic V, Bickenbach J, Schatteman GC CD34+ blood cells accelerate vascularization and healing of diabetic mouse skin wounds. J Vasc Res 2003, 40:368-377.

90. Horschitz S, Meyer-Lindenberg A, Schloss P: Generation of neuronal cells from human peripheral blood mononuclear cells. Neuroreport 2010, 21:185-190.

91. Liu Q, Guan L, Huang B, Li W, Su Q, Yu M, Xu X, Luo T, Lin S, Sun X, Chen M, Chen $X$ : Adult peripheral blood mononuclear cells transdifferentiate in vitro and integrate into the retina in vivo. Cell Biol Int 2011, 35:631-638.

92. Honma T, Honmou O, lihoshi $\mathrm{S}$, Harada K, Houkin K, Hamada H, Kocsis JD: Intravenous infusion of immortalized human mesenchymal stem cells protects against injury in a cerebral ischemia model in adult rat. Exp Neurol 2006, 199:56-66

93. Toma C, Pittenger MF, Cahill KS, Byrne BJ, Kessler PD: Human mesenchymal stem cells differentiate to a cardiomyocyte phenotype in the adult murine heart. Circulation 2002, 105:93-98.

94. Deshpande DM, Kim YS, Martinez T, Carmen J, Dike S, Shats I, Rubin LL, Drummond J, Krishnan C, Hoke A, Maragakis N, Shefner J, Rothstein JD, Kerr DA: Recovery from paralysis in adult rats using embryonic stem cells. Ann Neurol 2006, 60:32-44.

95. Kim S, Honmou O, Kato K, Nonaka T, Houkin K, Hamada H, Kocsis JD: Neural differentiation potential of peripheral blood- and bone-marrow-derived precursor cells. Brain Res 2006, 1123:27-33.

96. Kijima Y, Ishikawa M, Sunagawa T, Nakanishi K, Kamei N, Yamada K, Tanaka N, Kawamata S, Asahara T, Ochi M: Regeneration of peripheral nerve after transplantation of CD133+ cells derived from human peripheral blood. J Neurosurg 2009, 110:758-767.

97. Fahey TR, Sherry B, Tracey KJ, van Deventer S, Jones WN, Minei JP, Morgello S, Shires GT, Cerami A: Cytokine production in a model of wound healing: the appearance of MIP-1, MIP-2, cachectin/TNF and IL-1. Cytokine 1990, 2:92-99.

98. Schmidt M, Sun G, Stacey MA, Mori L, Mattoli S: Identification of circulating fibrocytes as precursors of bronchial myofibroblasts in asthma. J Immunol 2003, 171:380-389

99. Direkze NC, Forbes SJ, Brittan M, Hunt T, Jeffery R, Preston SL, Poulsom R, Hodivala-Dilke K, Alison MR, Wright NA: Multiple organ engraftment by bone-marrow-derived myofibroblasts and fibroblasts in bone-marrowtransplanted mice. Stem Cells 2003, 21:514-520.

100. Mori L, Bellini A, Stacey MA, Schmidt M, Mattoli S: Fibrocytes contribute to the myofibroblast population in wounded skin and originate from the bone marrow. Exp Cell Res 2005, 304:81-90.

101. Hu G, Liu P, Feng J, Jin Y: A novel population of mesenchymal progenitors with hematopoietic potential originated from CD14 peripheral blood mononuclear cells. Int J Med Sci 2010, 8:16-29.

102. Abe R, Donnelly SC, Peng T, Bucala R, Metz CN: Peripheral blood fibrocytes: differentiation pathway and migration to wound sites. J Immuno/ 2001 , 
166:7556-7562.

103. Takahashi K, Tanabe K, Ohnuki M, Narita M, Ichisaka T, Tomoda K, Yamanaka S: Induction of pluripotent stem cells from adult human fibroblasts by defined factors. Cell 2007, 131:861-872.

104. Yu J, Vodyanik MA, Smuga-Otto K, Antosiewicz-Bourget J, Frane JL, Tian S, Nie J, Jonsdottir GA, Ruotti V, Stewart R, Slukvin II, Thomson JA: Induced pluripotent stem cell lines derived from human somatic cells. Science 2007, 318:1917-1920.

105. Park IH, Zhao R, West JA, Yabuuchi A, Huo H, Ince TA, Lerou PH, Lensch MW, Daley GQ: Reprogramming of human somatic cells to pluripotency with defined factors. Nature 2008, 451:141-146.

106. Lowry WE, Richter L, Yachechko R, Pyle AD, Tchieu J, Sridharan R, Clark AT, Plath K: Generation of human induced pluripotent stem cells from dermal fibroblasts. Proc Natl Acad Sci U S A 2008, 105:2883-2888.

107. Ohmine S, Dietz AB, Deeds MC, Hartjes KA, Miller DR, Thatava T, Sakuma T, Kudva YC, Ikeda Y: Induced pluripotent stem cells from GMP-grade hematopoietic progenitor cells and mononuclear myeloid cells. Stem Cell Res Ther 2011, 2:46.

108. Zhang Y, Huang B: Peripheral blood stem cells: phenotypic diversity and potential clinical applications. Stem Cell Rev 2012, 8:917-925.

109. Till JE, McCulloch EA: A direct measurement of the radiation sensitivity of normal mouse bone marrow cells. Radiat Res 1961, 14:213-222.

110. Dorshkind K: Regulation of hematopoiesis by bone marrow stromal cells and their products. Annu Rev Immunol 1990, 8:111-137.

111. Pittenger MF, Mackay AM, Beck SC, Jaiswal RK, Douglas R, Mosca JD, Moorman MA, Simonetti DW, Craig S, Marshak DR: Multilineage potential of adult human mesenchymal stem cells. Science 1999, 284:143-147.

112. Grove JE, Bruscia E, Krause DS: Plasticity of bone marrow-derived stem cells. Stem Cells 2004, 22:487-500.

113. Horwitz EM, Prockop DJ, Fitzpatrick LA, Koo WW, Gordon PL, Neel M, Sussman M, Orchard P, Marx JC, Pyeritz RE, Brenner MK: Transplantability and therapeutic effects of bone marrow-derived mesenchymal cells in children with osteogenesis imperfecta. Nat Med 1999, 5:309-313.

114. Costa-Rodrigues J, Fernandes MH: Paracrine-mediated differentiation and activation of human haematopoietic osteoclast precursor cells by skin and gingival fibroblasts. Cell Prolif 2011, 44:264-273.

115. Uriel J: Cancer, retrodifferentiation, and the myth of Faust. Cancer Res 1976, 36:4269-4275

116. Hass R: Retrodifferentiation and cell death. Crit Rev Oncog 1994, 5:359-371

117. Chigira M: Self and nonself: duality of immune system. Med Hypotheses 1994, 43:6-10

118. Jiang Y, Jahagirdar BN, Reinhardt RL, Schwartz RE, Keene CD, Ortiz-Gonzalez XR, Reyes M, LenvikT, Lund T, Blackstad M, Du J, Aldrich S, Lisberg A, Low WC, Largaespada DA, Verfaillie CM: Pluripotency of mesenchymal stem cells derived from adult marrow. Nature 2002, 418:41-49.

119. Fujikawa Y, Quinn JM, Sabokbar A, McGee JO, Athanasou NA: The human osteoclast precursor circulates in the monocyte fraction. Endocrinology 1996, 137:4058-4060.

120. Quinn JM, Sabokbar A, Athanasou NA: Cells of the mononuclear phagocyte series differentiate into osteoclastic lacunar bone resorbing cells. J Pathol 1996, 179:106-111.

121. Vassilopoulos G, Wang PR, Russell DW: Transplanted bone marrow regenerates liver by cell fusion. Nature 2003, 422:901-904

122. Abrams RA, Glaubiger D, Appelbaum FR, Deisseroth AB: Result of attempted hematopoietic reconstitution using isologous, peripheral blood mononuclear cells: a case report. Blood 1980, 56:516-520.
123. Lagasse E, Connors H, Al-Dhalimy M, Reitsma M, Dohse M, Osborne L, Wang $X$, Finegold M, Weissman IL, Grompe M: Purified hematopoietic stem cells can differentiate into hepatocytes in vivo. Nat Med 2000, 6:1229-1234.

124. Lasky LC, Ash RC, Kersey JH, Zanjani ED, McCullough J: Collection of pluripotential hematopoietic stem cells by cytapheresis. Blood 1982, 59:822-827.

125. Rowley SD, Prather K, Bui KT, Appel M, Felt T, Bensinger WI: Collection of peripheral blood progenitor cells with an automated leukapheresis system. Transfusion 1999, 39:1200-1206.

126. Brauninger S, Bialleck H, Thorausch K, Felt T, Seifried E, Bonig H: Allogeneic donor peripheral blood "stem cell" apheresis: prospective comparison of two apheresis systems. Transfusion 2012, 52:1137-1145.

127. Nomura T, Honmou O, Harada K, Houkin K, Hamada H, Kocsis JD: I.V. infusion of brain-derived neurotrophic factor gene-modified human mesenchymal stem cells protects against injury in a cerebral ischemia model in adult rat. Neuroscience 2005, 136:161-169.

128. Lisa G, Barbara M, Dongmei W, Francis K, Fraser F, Mickie B: Identification of novel circulating human embryonic blood stem cells. Blood 2000, 96:1740-1747.

129. Hassan HT, Zeller W, Stockschlader M, Kruger W, Hoffknecht MM, Zander AR: Comparison between bone marrow and G-CSF-mobilized peripheral blood allografts undergoing clinical scale CD34+ cell selection. Stem Cells 1996, 14:419-429.

130. Urbano-Ispizua A, Rozman C, Martinez C, Marin P, Briones J, Rovira M, Feliz P, Viguria MC, Merino A, Sierra J, Mazzara R, Carreras E, Montserrat E: Rapid engraftment without significant graft-versus-host disease after allogeneic transplantation of CD34+ selected cells from peripheral blood. Blood 1997 89:3967-3973

131. Wingard JR, Hsu J, Hiemenz JW: Hematopoietic stem cell transplantation: an overview of infection risks and epidemiology. Infect Dis Clin North Am 2010, 24:257-272.

132. Okitsu O, Kiyokawa M, Oda T, Miyake K, Sato Y, Fujiwara H: Intrauterine administration of autologous peripheral blood mononuclear cells increases clinical pregnancy rates in frozen/thawed embryo transfer cycles of patients with repeated implantation failure. J Reprod Immunol 2011, 92:82-87.

133. Zhou J, Wang Z, Zhao X, Wang J, Sun H, Hu Y: An increase of Treg cells in the peripheral blood is associated with a better in vitro fertilization treatment outcome. Am J Reprod Immunol 2012, 68:100-106.

134. Ozturk A, Kucukardali Y, Tangi F, Erikci A, Uzun G, Bashekim C, Sen H, Terekec H, Narin Y, Ozyurt M, Ozkan S, Sayan O, Rodop O, Nalbant S, Sildıroglu O, Yalnız FF, Senkal IV, Sabuncu H, Oktenli C: Therapeutical potential of autologous peripheral blood mononuclear cell transplantation in patients with type 2 diabetic critical limb ischemia. J Diabetes Complications 2012 26:29-33.

135. DeRosa BA, Van Baaren JM, Dubey GK, Lee JM, Cuccaro ML, Vance JM, PericakVance MA, Dykxhoorn DM: Derivation of autism spectrum disorder-specific induced pluripotent stem cells from peripheral blood mononuclear cells. Neurosci Lett 2012, 516:9-14.

doi:10.1186/scrt139

Cite this article as: Zhang M, Huang B: The multi-differentiation potential of peripheral blood mononuclear cells. Stem Cell Research \& Therapy 2012, 3:48. 